\title{
E-Ticaret Sitelerinde Algılanan Sosyal Medya Pazarlaması Faaliyetlerinin E-Sadakate Etkisi \\ (Effect of e-Loyalty on Perceived Social Media Marketing Activities on e-Commerce Sites)
}

\section{Esma DURUKAL iDa Mustafa DOĞANER ${ }^{\text {iD }}{ }^{b}$ Ece ARMAĞAN ${ }^{\text {iD }}$}

a Nazilli İktisadi ve İdari Bilimler Fakültesi, Aydın Adnan Menderes Üniversitesi, Aydın, Türkiye. eacayip@adu.edu.tr

b Nazilli İktisadi ve İdari Bilimler Fakültesi, Aydın Adnan Menderes Üniversitesi, Aydın, Türkiye. mdoganer@adu.edu.tr

c Nazilli İktisadi ve İdari Bilimler Fakültesi, Aydın Adnan Menderes Üniversitesi, Aydın, Türkiye. earmagan@adu.edu.tr

\begin{tabular}{|c|c|}
\hline MAKALE BİLGİSİ & ÖZET \\
\hline $\begin{array}{l}\text { Anahtar Kelimeler: } \\
\text { Sosyal Medya Pazarlaması } \\
\text { E-Sadakat } \\
\text { E-Ticaret }\end{array}$ & $\begin{array}{l}\text { Amaç - Dijitalleşmenin giderek yaygınlaşması müşterilerin alışveriş alışkanlıklarının } \\
\text { değişmesine, buna bağlı olarak alışverişin e-alışverişe doğru kaymasına ve e-ticaret sitelerinin } \\
\text { kullanımının artmasına sebep olmuştur. Müşterilerin e-ticaret sitelerinde alışveriş yaparken } \\
\text { diğger müşteriler ile etkileşimde ve bilgi paylaşımında bulundukları sosyal medya, e-ticaret için } \\
\text { yaygın olarak benimsenen bir platform haline gelmiştir. Sosyal medya pazarlamasının, özellikle } \\
\text { e-ticarette iş alanında geniş çapta kabul görmesi bu çalışmanın önemini ortaya koymaktadır. Bu } \\
\text { çalışmanın amacı e-ticaret sitelerini kullanan müşterilerin algıladıkları sosyal medya } \\
\text { pazarlaması faaliyetlerinin e-sadakate etkisini ölçmektir. }\end{array}$ \\
\hline
\end{tabular}

Kabul Tarihi 5 Şubat 2019

Makale Kategorisi:

Yöntem - E-ticaret sitelerini kullanan 345 online müşteri üzerinde yapılan çalışmanın, anket soru formu; Yadav ve Rahman (2017) ve Al-Hawari, (2014) ölçekleri kullanılarak oluşturulmuş, analizleri ise SPSS programı ve yapısal eşitlik modellemesi LISREL programı ile yapılmıştır.

Araştırma Makalesi

Bulgular - Elde edilen araştırma sonuçlarına göre, e-ticaret sitelerinden alışveriş yapan müşteriler tarafından algılanan sosyal medya pazarlaması faaliyetlerinin e-sadakati olumlu yönde etkilediği, müşterilerin e-ticaret sitelerinden ürün satın alırken diğer müşterilerin sosyal medyada yaptıkları yorum ve önerilerini dikkate aldığı sonucuna varılmıştır.

Tartışma - Gelecekte sosyal medya pazarlamasına verilen önemin giderek artması ve e-ticaret sektöründe bu payın diğerden fazla artmasının üzerinde durulacaktır.

\begin{tabular}{ll}
\hline ARTICLE INFO & ABSTRACT \\
\hline Keywords: & Purpose - Increasing digitalization has led to changes in customers' shopping habits, resulting \\
Social Media Marketing & in the shift of shopping to e-shopping and increasing use of e-commerce sites. Social media, \\
E-Loyalty & where customers are interacting with other customers and sharing information while shopping \\
E-Commerce & on e-commerce sites, have become a widely adopted platform for e-commerce. The fact that \\
& social media marketing, especially in e-commerce, is widely acknowledged in the business field \\
is important for this work. The purpose of this study is to measure the e-loyalty effect of social & media marketing that customers using e-commerce sites are perceiving.
\end{tabular}

Revised 27 January 2019

Accepted 5 February 2019

Article Classification:

Research Article
Design/methodology/approach - The survey of 345 online customers using e-commerce sites, survey questionnaire; Yadav and Rahman (2017) and Al-Hawari, (2014) scales were used for analysis the SPSS program and the structural equation modeling were done with the LISREL program.

Finding - According to the research results, social media marketing perceived by customers who shopped from e-commerce sites affected e-loyalty positively and when customers were purchasing products from e-commerce sites, other customers came to the comments and suggestions they made in social media.

Discussion - The management of the importance given in the social media market in the future and the sales-commerce sector will focus on the art of this share more than the other. 


\section{Giriş}

İnternet kullanımının toplumun tüm kesimlerinde yaygınlaşması, tüketicilerin yaşantısında birçok alanda köklü değişime neden olmuş, bunun başında tutum ve davranışlar yer almıştır. Bu değişimle birlikte, işletmeler için sosyal medya platformu pazarlama faaliyetleri içinde daha geniş çapta yer almıştır (Alan vd., 2018: 536). Türkiye, sosyal medya kanallarının olarak aktif kullanıldığı ülkelerden biridir. Küresel alanda faaliyet gösteren dijital pazarlama ajansı "We are social" tarafından yayınlanan "Dijital in 2016 Global Overview" raporunda dünyada internet kullanıcılarının nüfusa oranı \% 35 iken, sosyal medya kullanıcılarının genel nüfusa oranı \%26 düzeyindedir. Dijital in 2017 Global Overview" raporuna Türkiye nüfusunun \% 60'1 ortalama 48 milyon kişi internet kullanıcısı ve bu internet kullanıcılarının \% 87'sini oluşturan 41,5 milyon kişi tarafından internet sürekli olarak kullanılmaktadır. Ayrıca aktif sosyal medya kullanıcısı 42 milyondur. 2017 yılında ülkemiz tüketicilerinin her gün internette geçirdikleri süre olan ortalama 7 saatin yaklaşık 3 saatini sosyal medya kanallarında geçirmektedirler. Bu durum Türkiye'de sosyal medya kullanımına karşı ilginin ne kadar fazla olduğunu göstermektedir Kullanıcıların sosyal ağlara girmek ve e-posta okumak dışında en sık gerçekleştirdiği davranış, online ürün bilgisi aramaktır. Türkiye'de e-ticaret kullanan bireylerin \% 52'si satın almak üzereyken online hizmet veya ürün aradığı söylenebilir. Ayrıca bu bireylerin \% 43'ünün satın almayı yaptığı gerçeği göz önünde alındığında (We are social 2018, https://www.slideshare.net) e-ticaret sitelerinin kullanıcılar tarafından aktif bir şekilde tercih edilen faaliyetler bütünü olduğunu söyleyebiliriz.

Bu çalışmanın amacı e-ticaret siteleri için müşterilerle ilişki kurmada önemli bir kanal olan sosyal medya üzerinden yapılan pazarlama faaliyetlerinin, e-sadakate etkisini kapsamlı bir araştırma modeli ile değerlendirmektir.

\section{Kavramsal Çerçeve}

İnternet ekonomisinin hızla gelişmesi, sadece orjinal ekonomik düzeni bozmakla kalmamış, aynı zamanda ekonomik büyümede, şirketler arası rekabette ve hatta uluslararası rekabette önemli bir faktör haline gelmiştir. Bu ekonominin istikrarlı büyümesi ve şaşırtıcı derecede yüksek pazar payı gelecekteki rekabetin önemini artırmaktadır. İnternet ekonomisiyle başlayan e-ticaret, online mağazaların yaratılmasını yeni bir ticari sanal varlık olarak ortaya çıkarmıştır (Cui vd., 2017: 10). Dünyada bilgi teknolojisinin ortaya çıkması, dünya çapında piyasa yapısında büyük bir değişim getirmiştir. Bilgi teknolojisi, elektronik ticaretin ortaya çıktığ1 dijital ekonomi için bir platform oluşturmuştur. İnternet teknolojisi, geleneksel ticaret mağazasından farklı olarak coğrafi sınırlamalar olmaksızın dünya çapındaki insanlara, her an her yerden alışveriş yapma imkanı sunmaktadır (Sin vd., 2012: 326). E-ticaret, satılan ürünlerin ödeme süreci ve teslim sürecinin fiziksel veya dijital olma derecesine göre farklılık göstermektedir. E-ticarette dijital ve fiziksel bileşim içeren, amazon.com sitesinden bir kitap satın alındığında kitap fiziksel olarak teslim edildiği için kısmi elektronik ticaret olarak adlandırılan, e-ticaret olarak kabul edilir. Bununla birlikte Egghead sitesinden yazılım satın almak, üründe teslimatın ve ödemenin tamamının dijital olması saf e-ticarettir (Akar, 2015: 21). E-ticaretin müşterilerine sunduğu ekonomik fiyatlar, detaylı ürün özellikleri, ürün bilgileri ve fiyatları karşılaştırma olanağı, geniş ürün seçenekleri ve teslimatta sağlanan kolaylıklar, hızlı büyümeyi sağlayan en önemli faktörlerdir (Yaralı ve Kırık, 2017: 526).

E-ticaret, günümüz dünya ekonomisinin belirsizliğine rağmen muazzam bir artış göstermiştir (Ludin ve Cheng, 2014: 462). Geçtiğimiz on yıl boyunca, internet teknolojisi insanların yaşam tarzını önemli ölçüde değiştirmiştir. E-ticaret hızla gelişmiş ve online alışveriş, mal satın almak için popüler bir yöntem haline gelmiştir. Türkiye bilgi ve iletişim teknolojileri sektörü 117 milyar TL'ye ulaşmıştır. 2016 yılı itibariyle 30,8 milyar TL olan e-ticaret pazar büyüklügü 2017 yılında 42,2 milyar TL'ye ulaşmış ve bir önceki yıla göre \% 37 oranında büyüme kaydetmiştir. Bu pazarın 4,4 milyar TL'si online yasal bahis, 14,8 milyar TL'si tatil ve seyahat harcamaları, 8,2 milyar TL'si çok kanallı perakende harcamaları ve 14,7 milyar TL'si sadece online perakende harcamaları oluşturmaktadır. Bu harcamalar içerisinde tatil ve seyahat harcamaları $\% 47$ büyüme kaydederek en fazla büyüyen ve en fazla tercih edilen online harcamalardır. Gelişmiş ülkelerde online perakende harcamalarının toplam perakende harcamaları içerisindeki payı ortalama \% 9,8 ve İngiltere bu ülkeler arasında \% 15,7'i en fazla paya sahiptir. Gelişmekte olan ülkelerde bu pay ortalama \% 4,8 ve Çin bu ülkeler arasında \%20,4 ile en fazla paya sahiptir. Türkiye ise online satış pazarının ülke içindeki payı \% 4,1 ile giderek artan bir ivme göstermektedir (TÜBİSAD, 2018). 
Sosyal medya, bilgiyi bulma ve satın alma yöntemlerini geleneksel hale getirme konusunda geleneksel yöntemler geliştirmekte ve bunun sonucunda yeni sosyal ve ekonomik sonuçlar doğurmaktadır. Sosyal medyaya dayalı pazarlama, kısmen sosyal medya reklamlarına yönelik geri çağırma oranlarının geleneksel reklamlara oranla\% 55 daha fazla olduğu gerçeği nedeniyle dikkat çekerken, 2013 raporunda sosyal medyanın tüm satın alımların\% 90'ını etkilediği tespit edilmiştir (Seo ve Park, 2018: 36). Son on yılda, sosyal medya pazarlaması, müşteri ilişkilerinin değişen yönlerini vurgulayan baskın bir araştırma akışı olarak ortaya çıkmıştır (Yadav ve Rahman 2017:1). İnternetin gelişimi, web işlevini daha iyi hale getirerek; Web $2.0^{\prime}$ yi, blog ve sosyal ağ oluşturmayı sağlayan ve web 1.0'dan daha fazla kullanıcı tarafından oluşturulan içerik haline getirmiştir. Web 2.0'ın gelişimi ile sosyal medya giderek daha popüler hale gelmiştir. Web 2.0'in işlevi, online alıcıların dünyadaki işlemlerini nasıl gerçekleştirdiğini değiştirmiştir. "Sosyal medya, insanların fotoğraf, video, müzik, anlayış ve algılarını içeren görüş ve deneyimlerini paylaştıkları çevrimiçi platform ve araçları ifade eder" (Arslan ve Baycan, 2018: 273). Sosyal ağ, web'de ilk ortaya çıktığında, sadece video oyunları oynayan çlgın gençler tarafından kullanılmıştır (Sin vd., 2012: 327).

Müşteriler, bir satın alma yapmadan önce ürün ve hizmetlerini değerlendirmek için Facebook, Twitter vb. sosyal sitelerdeki kullanıcıların yorumlarını dikkate almaktadır (Yang vd., 2016: 63). Zamanının büyük bir kısmını internet ortamında geçiren günümüz dijital müşterilerini işletmelerine kazandırmayı hedefleyen şirketler diğer pazarlama araçlarını kullanarak yaptıkları tanıtım ve reklam yatırımlarını sosyal medya için de ayırmaktadırlar. Sosyal medyanın diğer pazarlama araçlarına göre daha ekonomik olması ve doğrudan kişiye özel pazarlama stratejileri uygulayabilme avantajı nedeniyle popülerliği giderek artmaktadır (Yaralı ve Kırık, 2017: 526). Sosyal medya, sosyal ağ siteleri, bloglar, wiki'ler, mikroblog siteleri gibi çeşitli biçimlerde olabilir. Günümüzde en çok kullanılan sosyal medya platformları Facebook, Twitter ve içerik paylaşım sitesi YouTube'dur. Bu kanallar ağızdan ağıza iletişim potansiyelinin yüksek olduğu sosyal medya platformlarıdır (Köker, vd. 2013: 147). Mevcut literatür, sosyal medya pazarlamasının endüstri ve akademi alanındaki popülerliğinin yanı sıra, tanımlanması bağlamında kolektif bir anlaşmaya varamamış, mevcut ve potansiyel müşterilerle bağlantı kurma ve etkileşim kurmayı, müşteri ilişkileri kurma aracı olarak tanımlamaktadır (Yadav ve Rahman, 2017: 2). Sosyal medyanın özelleştirilmesi, şirketlerin markalarının benzersizliğini iletmeleri ve müşterilerin bu markalara olan bağlılıklarını ve sadakatlerini geliştirmeleri için bir araçtır (Seo ve Park, 2018: 37).

Sosyal medya pazarlaması; pazarlama faaliyetlerini sosyal medya kanalları ile gerçekleştirmek ve bu faaliyetlerle ilgili paylaşımlarda bulunmaktır. Müşteriler ile iletişim sağlamak, müşterilerde farkındalık yaratmak, markanın web sitesi trafiğini artırmak, markayı takip eden kişi sayısını artırmak ve ilgili bağlantıları web sitesine yönlendirmek gibi temel amaçları bulunmaktadır (Telli-Yamamoto ve KaramanlıŞekeroğlu, 2014: 13). Sosyal medya pazarlamasının başarısının sürdürülebilir olması için yapılan yatırımların etkin bir şekilde kullanılması gerekmektedir. Sosyal medya pazarlamasının sürekliliği sağlanmadığında sanal ortamlarda firmaların imaj ve satışlarını olumsuz yönde etkileyecek bilgilerin yayılması engellenemeyecektir (Barutçu ve Tomaş, 2013: 10).

E-ticaret ortamı altındaki tüketici davranışı, geleneksel alışveriş ortamından daha karmaşıktır. Online tüketiciler hizmet kalitesi ve dakikliği gibi konularda yüksek beklentilere sahiptirler. Bu tüketiciler aynı zamanda e-ticaret şirketlerinden duygusal tatmin ve karakter gücü gibi diğer değerlerin de yerine varlığını talep etmektedirler. Tüm bunlar online tüketicilerin psikolojisinin araştırılması gerektiği gerçeğini ortaya çıkarmaktadır. Online alışverişe ait değerleri istikrarlı bir pazar payını korumak ve e-ticaret pazarında sürekli olarak gelişmek için açıklığa kavuşturulmalıdır. Bunun için online mağazaların müşteri değerlerini yaratmasını kolaylaştıran e-memnuniyet ve kalıcı e-sadakat sağlanmalıdır (Cui vd., 2017: 10). Pazarlama literatüründe sadakat kavramı geniş ölçüde tartışılmış olmasına rağmen e-sadakat çalışmaları 2000 yılında başlamıştır. E-sadakat, müşterinin gelecekte istikrarlı bir ilişkiyi sürdürme, ziyaretlerinin tekrarlanması, online ürün / hizmet satın alımları ile ilgili olarak, alternatifler arasında ilk tercih olarak şirketin web sitesini kullanması ve olumlu inançlar ile desteklenen olumlu duygular olarak ifade edilmektedir. (Lopez-Miguens ve Gonzalez Vazquez, 2017: 398). E-sadakat, müşterilerin tekrar satın alma davranışına yol açan e-ticarete doğru tercih edilen tutumudur. Sadakat her iki tarafın da katkısını gerektiren bir gelişim sürecidir; diğer bir deyişle, bir online perakendeci ve bir müşteri, karşılıklı sadakatini daha iyi bir şekilde beslemede birbirlerini desteklemeli ve yardımcı olmalıdır. Bu gerçeği göz önünde bulundurarak, online bir perakendecinin e- 
sadakati elde etmesi için, müşterilerine mükemmel bir online alışveriş deneyimi sunarak müşteri memnuniyetini sağlayacak ihtiyaçları karşılaması gerekmektedir (Ludin ve Cheng, 2014: 455).

E-sadakat, online tüketicilerin geçmiş satın alma deneyimine ve gelecekteki beklentilere dayanarak e-ticaret web sitelerini yeniden ziyaret etme istekliliği, artan satın alma sıklığı, düşük fiyat duyarlılı̆̆ı, satın alma sayısı ve değeri ile ifade edilir. E-sadakat seviyesinde e-memnuniyet, tüketici ihtiyaç trendindeki değişim veya tüketicinin alışveriş değeri trendinde doğru bir şekilde anlaşılmalıdır. E-ticaretin gelişmesiyle, büyük bir alışveriş değeri yaratmak ve sunmak, satıcılar arasında yaygın bir uygulama haline gelmiştir. Bir işletme, değerini göstererek sadık müşterileriyle sağlıklı ilişkiler kurabilir ve ihtiyaçlarını karşılayarak tüketiciye tatmin edici deneyimler sağlayabilir. Bir işletme ayrıca müşteri elde tutma oranını ve pazar payını bir fayda olarak daha da artırır. Değer memnun tüketicileri üretir, devam eden memnuniyet ise sadık olanları üretir. Dolayısıyla, alışveriş değeri, bir kuruluşta e-sadakati kolaylaştırmak için önemli bir faktördür (Cui vd., 2017: 12). Sadık müşteriler, şirketin pazar payı ve karlılığı ile olan ilişkilerinden dolayı, herhangi bir işletmenin hayatta kalması için çok önemli kabul edilir. Müşteri sadakatinin duygusal yönleri, diğer müşterilere olumlu bir marka önermek, aynı şirketle iş yapmaya devam etmek ve ilk tercih olarak uygun bir marka düşünmek olabilir (Al-Hawari, 2014: 540).

Geçtiğimiz yirmi yıl içinde e-ticaret sitelerinin çoğalmasını destekleyen internet alışverişi alışverişin doğasını değiştirerek online alışverişe geçti. İnternet çağında bir başka devrim ise Web 2.0'a interaktif bileşenler sağlayan Web 2.0 ve Web 2.0'ın en önemli uygulaması sosyal medyadır. Sosyal medya sitelerinin başlıcaları olan Facebook ve Twitter'ın artan kabulü, genellikle sosyal ticaret olarak bilinen, e-ticaretin yenilikçi iş modelleri için umutlar açmıştır.

Sosyal ticaret ve sosyal alışveriş, insanların online pazarlarda ve topluluklarda ürün ve hizmetlerin pazarlanması ve satışına aktif olarak katılmalarını sağlayan internet tabanlı sosyal medya formlarıdır. Bu uygulamaların online alışveriş / e ticaret ve sosyal medyayı birleştirdiği söylenebilir. Dolayısıyla, sosyal ticaret, e-ticaretin günlük işlem ve faaliyetlerini desteklemek için sosyal teknolojileri kapsayan elektronik ticaretin bir alt kümesi olarak düşünülebilir (Yadav ve Rahman, 2017: 2).

Günümüzde geleneksel ticaret yerine e-ticaret'e yönelen çoğu firma internet siteleri üzerinden yapılan eticaret yerine de sosyal medya kanalları aracılı̆̆ıyla yapılan e-ticareti kullanmaya başlamışlardır. Sosyal medya siteleri e-ticaret yatırımlarının yapıldığı ve ciddi önem kazandığı bir alan haline gelmiştir (Yaralı ve Kırık, 2017: 526). Şu anda, e-ticaret sosyal medya aracılığıyla yapılabilmekte ve daha fazla potansiyel alıcıya ulaşılmasını sağlamaktadır. Kullanıcıların kendi içeriklerini (videolar, müzik, fotoğraflar, kişisel bilgiler, bloglar ve yazılım uygulamaları gibi) dağıtmasına olanak tanıyan Facebook, MySpace, Twitter, YouTube ve Photobucket gibi şirketler, öne çıkmaya başladı. Bu, sosyal medyanın potansiyelini yeni bir e-ticaret platformu haline getirebilir. Sosyal ağın gücü, gelecekte e-ticaretin gelişmesini artıracaktır. İşletmeler ve bireyler, online işlerini yürütmek için sosyal medyayı kullanmaya başladılar. Dolayısıyla, e-ticaretin artık sosyal ağda ortaya çıkması hayati bir öneme sahiptir çünkü e-ticaret artık daha fazla müşteri ya da toplum güdümlüdür. İnsanlar artık bilgi, eğitim, ağ ve ticaret için fiziksel alanın ötesine ulaşabilecekleri bir ağ toplumunda yaşıyorlar. Dahası, toplumların sosyal ve ekonomik refahı ağa bağlanmaktadır. İş bağlamında bu, müşterilerin sosyal ağa daha fazla katılım gösterdiği ve pazarlamacıların sosyal ağ aracılığıyla tüketicileri izlemeli ve yanıt vermesi gerektiği anlamına gelir (Sin ve di ̆., 2012: 327). İnternet teknolojisinin gelişimiyle birlikte milyarlarca müşterinin sosyal ağlar aracıllğıyla bir araya gelmesi işletmeler için makro bir alışveriş ağı oluşmaktadır. Bu durum sosyal ağları işletmeler için birer pazarlama aracı haline dönüştürmekte ve hedef kitleye ulaşmak için en kısa yolu oluşturmaktadır (Yaralı ve Kırık, 2017: 526). Son yıllarda, e-ticaret ve sosyal ağ arasındaki sınırlar giderek daha da artmıştır. EBay gibi e-ticaret siteleri, gerçek zamanlı durum güncellemeleri ve alıcıları ile satıcıları arasındaki etkileşimler dahil olmak üzere sosyal ağların özelliklerinin çoğuna sahiptir. Bazı e-ticaret siteleri, yeni kullanıcıların Facebook, Twitter veya Google+ gibi sosyal ağ hizmetlerinden mevcut giriş bilgileriyle oturum açmalarını sağlayan sosyal oturum açma mekanizmasını da desteklemektedir. Hem Facebook hem de Twitter, kullanıcıların reklamları veya diğer yayınlardaki öğeleri satın almak için bir "satın al" düğmesini tıklayarak doğrudan web sitelerinden ürünler satın almalarına olanak tanıyan yeni bir özellik sunmuştur. Çin'de, e-ticaret şirketi ALIBABA, ürün reklamlarının doğrudan SINA WEIBO kullanıcılarına teslim edilebildiği SINA WEIBO'da stratejik bir yatırım yapmıştır. Sosyal paylaşım sitelerinde e-ticaret faaliyetleri yürütme eğilimi ile birlikte, ürün önerisi 
sistemlerinin geliştirilmesi için sosyal ağ sitelerinden çıkarılan bilginin kullanılması önemlidir (Zhao vd.,2016: 1).

E-ticaret sektöründe şu anda trend olan sosyal medya pazarlaması faaliyetlerinin gelecekte artarak devam edeceği söylenebilir. Kullanıcı derecelendirmeleri, incelemeler, öneriler, istek listeleri (public), Facebook ve Twitter üzerinden satın alınan ürünlerin paylaşımı gibi bileşenlerinin dahil edilmesi, sosyal medya pazarlamasının bir parçasıdır ve Amazon, Flipkart vb. e-ticaret şirketleri tarafından yaygın olarak benimsenmiştir. Facebook universal login veya 'Facebook Connect' özelliği, e-ticarette sosyal medya pazarlama faaliyetlerini de kolaylaştırmaktadır (Yadav ve Rahman, 2017: 3).

E-ticarette algılanan sosyal medya pazarlamasının boyutları incelendiğinde;

Etkileşim: E-ticaretin sosyal medyasının müşterileri, içerik ve görüşlerini şirket ve diğer müşterilerle paylaşmasına olanak tanıdığı kapsam olarak değerlendirilmektedir. Bilişim: E-ticaret sosyal medyanın doğru, yararlı ve kapsamlı bilgi sunma derecesi olarak ifade edilir. Kişiselleştirme: E-ticaret sosyal medyanın bir müşterinin tercihlerini yerine getirmesi için özel hizmetler sunma derecesi olarak ifade edilmektedir (Yadav ve Rahman, 2017: 6). Bugün, birçok e-ticaret web sitesi Netflix (film önerileri), Amazon (ürün önerileri) ve Yelp (iş incelemeleri) dahil olmak üzere içeriklerini kişiselleştiriyor. Ancak, e-ticaret sitelerinde kişiselleştirme, gösterilen ürünleri manipüle ederek (fiyat yönlendirmesi) veya ürünlerin fiyatlarını (fiyat ayrımcılı̆̆ı) özelleştirerek kullanıcının dezavantajında da kullanılabilir. Kişiselleştirme, günümüzün en çok ziyaret edilen web siteleri arasında her yerde bulunan bir özelliktir. Google gibi arama motorları, Netflix gibi akış ortamı hizmetleri ve Yelp gibi öneri siteleri, her bir kullanıcıya içeriği uyarlamak için sofistike algoritmalar kullanır. Birçok durumda, kişiselleştirme kullanıcılar için avantajlar sağlar: örneğin, bir kullanıcı Google'da \ Apple gibi belirsiz bir sorguyla arama yaptığında, birden fazla potansiyel yorum vardır. Arama sonuçlarını kişiselleştirerek (örneğin, kullanıcının geçmişini alarak) Google, hesaba katar, potansiyel olarak örneğin, meyve bahçeleri yerine bilgisayar ürünleri gibi daha ilgili sonuçları döndürür (Hannak vd., 2014: 305).Trend: E-ticaretin sosyal medyasının modaya uygun içerik sunma derecesidir. Word-of-Mouth: E ticaret müşterilerinin e-ticaret hakkındaki deneyimlerini sosyal medyada ne derece tavsiye edip paylaştıklarını ifade eder (Yadav ve Rahman, 2017, s. 6). E-WOM, müşteriler tarafından ağ üzerinden sağlanan bir ürün veya hizmet hakkında yapılan yorumdur. Müşterilerin güven ve satın alma davranışları üzerinde doğrudan bir etkisi vardır. Geleneksel WOM'un sınırlamalarının üstesinden gelebilir, bu nedenle e-ticaret, bilgi sistemleri ve pazarlama alanında geniş çapta analiz edilmiştir (Yang vd., 2016: 63).

\section{Araştırmanın Metodolojisi}

\subsection{Araştırma Evreni ve Örneklemi}

Araştırmanın evrenini, Türkiye'de e-ticaret sitesi kullanan müşteriler oluşturmaktadır. Anket soru formu, Google Forms üzerinden hazırlanmış ve 25 Mayıs 2018 - 10 Haziran 2018 tarihleri arasında online olarak veriler toplanmıştır. Araştırmanın örnekleminde ise tesadüfî olmayan yöntemlerden kolayda örneklem yöntemi kullanılmıştır. Müşterilerin yanıtladığı 382 anket soru formu içerisinden 347 adet geçerli anket soru formu araştırma kapsamına dahil edilmiştir.

\subsection{Anket Soru Formunun Oluşturulması}

Anket soru formu iki bölümden oluşmaktadır. Birinci bölümünde, cevaplayıcıların demografik özellikleri ile ilgili, e-ticaret sitesi ve sosyal medya kullanımlarına ilişkin 16 ifade yer almaktadır. İkinci bölümünde ise, eticarette sosyal medya pazarlaması boyutları ile e-sadakate ilişkin 26 ifade yer almaktadır. Araştırmanın ölçeği, "etkileşimlilik (6 ifade)", "bilişim (4 ifade)", "kişiselleştirme (4 ifade)", "trend (4 ifade)" ve "e-wom (4 ifade)" olarak ifade edilen e-ticarette sosyal medya pazarlaması boyutları ile "e-sadakat (4 ifade)" boyutunu ölçen ifadelerden oluşmaktadır (Yadav ve Rahman, 2017; Al-Hawari, 2014). Müşterilerin anket soru formunda verilen ifadelere ne derecede katılıp, katılmadığını belirlemek için 5'li Likert ölçeği kullanılmıştır.

\subsection{Araştırmanın Modeli ve Hipotezler}

Şekil 1'de verilen toplam 26 adet likert tipi ifadeden oluşan araştırma modeline göre, e-ticarette sosyal medya pazarlaması boyutları "etkileşimlilik (6 ifade)", "bilişim (4 ifade)", "kişiselleştirme (4 ifade), "trend (4 
E. Durukal - M. Doğaner - E. Armağan 11/1 (2019) 129-143

ifade)" ve "e-wom (4 ifade)" olarak gösterilmektedir. E-ticarette sosyal medya pazarlamasının beş boyutunun "e-sadakat (4 ifade)" üzerine etkisi ölçülecektir.

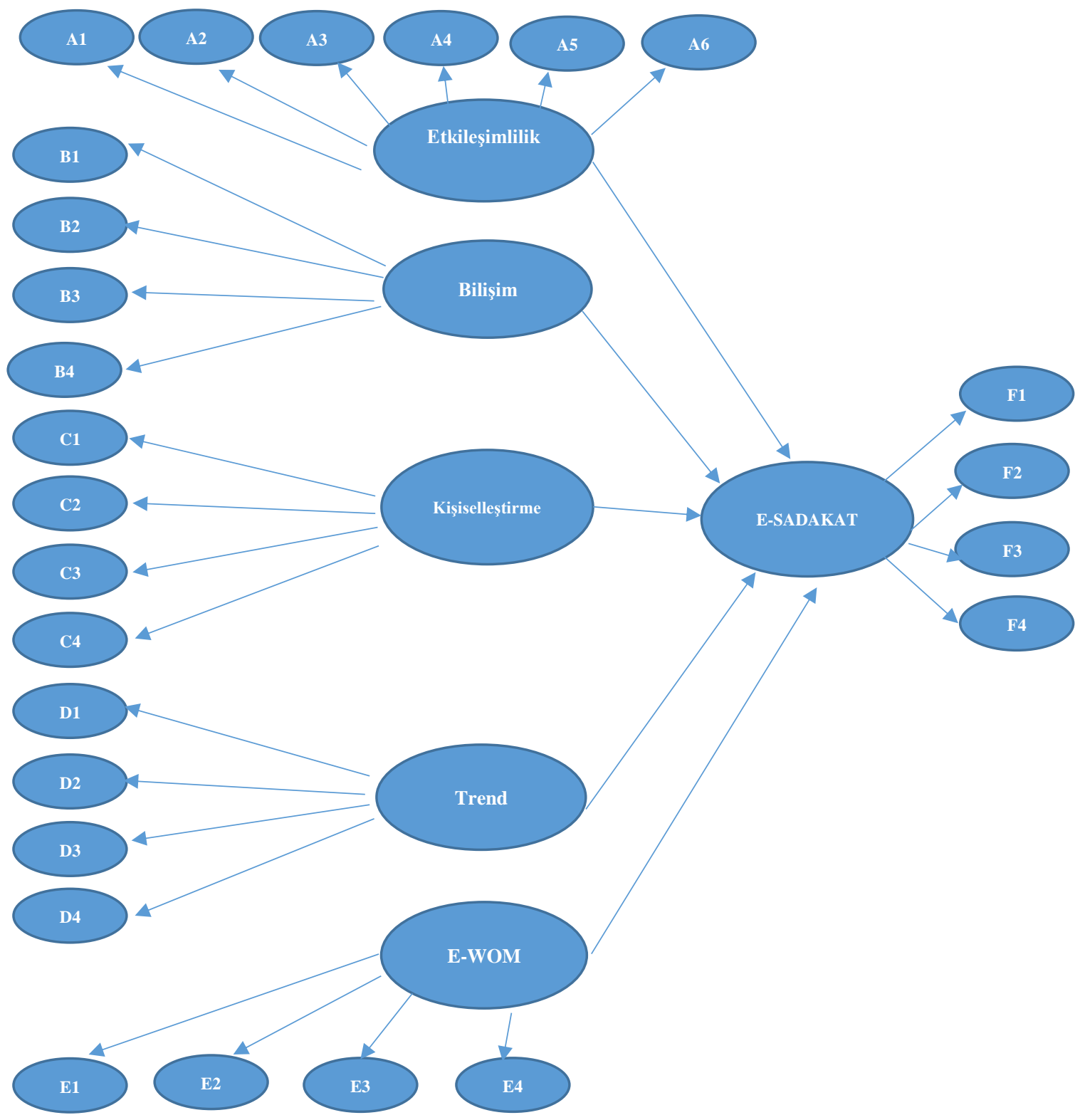

Şekil 1: Araştırma Modeli

Araştırmanın hipotezleri aşağıdaki gibi sıralanmaktadır:

H1: Algılanan sosyal medya pazarlaması etkileşimlilik boyutunun e-sadakate olumlu etkisi vardır.

$\mathrm{H}_{2}$ : Algılanan sosyal medya pazarlaması bilişim boyutunun e-sadakate olumlu etkisi vardır.

$\mathrm{H}_{3}$ : Algılanan sosyal medya pazarlaması kişiselleştirme boyutunun e-sadakate olumlu etkisi vardır.

$\mathrm{H}_{4}$ : Algilanan sosyal medya pazarlaması trend boyutunun e-sadakate olumlu etkisi vardır.

H5: Algilanan sosyal medya pazarlaması e-wom boyutunun e-sadakate olumlu etkisi vardır.

\section{Bulgular}

\subsection{Katılımcıların tanımlayıcı istatistiklerine ilişkin bulgular}

Katılımcıların cinsiyet, medeni durum, çalışma durumu, eğitimi durumu, yaş, aylık gelirine göre dağılımları Tablo 1'de verilmektedir. Araştırmaya katılanların (212) kişi\% 61,1'ini kadın, (135) kişi \% 38,9'unu erkek müşteriler oluşturmaktadır. Katılımcıların medeni durumları incelendiğinde (151) kişi \% 43,5'u bekar, (196) kişi \% 56,5'u evli müşterilerden oluşmaktadır. Çalışma durumuna bakıldığında katılımcıların, özel sektör çalışanı (89) kişi \% 25,6 oranı ile en fazla gözleme sahip olan gruptur. 
E. Durukal - M. Doğaner - E. Armağan 11/1 (2019) 129-143

Tablo 1 Katılımcıların Demografik Bilgileri

\begin{tabular}{|c|c|c|c|c|c|c|c|}
\hline \multicolumn{2}{|l|}{ Değişken } & \multirow{2}{*}{$\begin{array}{r}\text { Frekans } \\
212\end{array}$} & \multirow{2}{*}{$\begin{array}{l}\text { Yüzde } \\
61,1\end{array}$} & \multicolumn{2}{|c|}{ Değişken } & \multirow{2}{*}{$\begin{array}{r}\text { Frekans } \\
2\end{array}$} & \multirow{2}{*}{$\frac{\text { Yüzde }}{0,6}$} \\
\hline Cinsiyet & Kadın & & & Yaş & $15-19$ & & \\
\hline & Erkek & 135 & 38,9 & & $20-29$ & 123 & 35,4 \\
\hline \multirow{2}{*}{$\begin{array}{l}\text { Medeni } \\
\text { Durum }\end{array}$} & Bekar & 151 & 43,5 & & 30-39 & 114 & 32,9 \\
\hline & Evli & 196 & 56,5 & & $40-49$ & 54 & 15,6 \\
\hline \multirow{6}{*}{$\begin{array}{l}\text { Çalışma } \\
\text { Durumu }\end{array}$} & Çalışmiyor & 40 & 11,5 & & $50-59$ & 46 & 13,3 \\
\hline & Emekli & 25 & 7,2 & & $\begin{array}{ll}60 & \text { yaş } \\
\text { üzeri } & \end{array}$ & 8 & 2,3 \\
\hline & İşyeri sahibi & 34 & 9,8 & $\begin{array}{l}\text { Aylik } \\
\text { Gelir }\end{array}$ & $\begin{array}{l}1000 \\
\text { TL'den az }\end{array}$ & 72 & 20,7 \\
\hline & Öğrenci & 84 & 24,2 & & $1001-2000$ & 61 & 17,6 \\
\hline & Kamu çalışanı & 75 & 21,6 & & $2001-3000$ & 62 & 17,9 \\
\hline & Özel sektör çalışanı & 89 & 25,6 & & $3001-4000$ & 45 & 13,0 \\
\hline \multirow{5}{*}{$\begin{array}{l}\text { Eğitim } \\
\text { Durumu }\end{array}$} & Ortaokul & 4 & 1,2 & & $4001-5000$ & 35 & 10,1 \\
\hline & Lise & 25 & 7,2 & & $5001-6000$ & 20 & 5,8 \\
\hline & Önlisans & 58 & 16,7 & & $6001-7000$ & 17 & 4,9 \\
\hline & Lisans & 189 & 54,5 & & $7001-8000$ & 2 & 0,6 \\
\hline & Lisansüstü & 71 & 20,5 & & $\begin{array}{ll}8000 & \text { ve } \\
\text { üzeri } & \end{array}$ & 33 & 9,5 \\
\hline
\end{tabular}

Eğitim durumu açısından katılımcılar arasında en fazla gözleme sahip olan (189) kişi \% 54,5 oran ile lisans mezunudur. Katılımcıların yaş değişkenleri incelendiğinde en fazla gözleme sahip olan (123) kişi \% 35,4'ü 20-29 yaş aralığı müşterilerden oluşmaktadır. Ayrıca aylık gelir bakımından katılımcılardan en az gözleme sahip olduğu 7001-8000 TL aylık geliri olan müşteriler oluşturmaktadır.

Tablo 2 incelendiğinde araştırmaya katılan kullanıcıların \% 96,3 gibi çarpıcı bir çoğunluğunun sosyal medyayı hergün kullandığı sonucu görülmektedir. Katılımcıların \% 72'sinin e-ticaret marka sayfalarını takip ettiği, \% 76,9'unun e-ticaret sitelerinde hesabı olduğu, \% 43,2'sinin e-ticaret sitelerinin sosyal medyada bulunan ürün bağlantılarından mal satın aldığı, \% 54,5'inin e-ticaret sitelerine derecelendirme yapıldığı, $\% 45,2^{\prime}$ sinin e-ticaret sitelerine yorum ve öneri yaptı̆̆ görülmektedir.

Tablo 2 Katılımcıların Sosyal Medyada E-ticaret Sitelerini Kullanımlarına İlişkin Bilgiler

\begin{tabular}{|c|c|c|c|}
\hline & Değişkenler & Frekans & Yüzde \\
\hline \multirow[t]{2}{*}{ Sosyal medyanın hergün kullanımı kullanımı } & Evet & 334 & $\% 96,3$ \\
\hline & Hayır & 13 & $\% 3,7$ \\
\hline \multirow[t]{2}{*}{ Sosyal medyada e-ticaret marka sayfalarının takibi } & Evet & 250 & $\% 72,0$ \\
\hline & Hayır & 97 & $\% 28,0$ \\
\hline \multirow[t]{2}{*}{ E-ticaret sitelerinde hesabın olması } & Evet & 267 & $\% 76,9$ \\
\hline & Hayır & 80 & $\% 23,1$ \\
\hline \multirow{2}{*}{$\begin{array}{l}\text { E-ticaret sitelerinin sosyal medyada bulunan ürün } \\
\text { bağlantılarından mal satın alınması }\end{array}$} & Evet & 150 & $\% 43,2$ \\
\hline & Hayır & 197 & $\% 56,8$ \\
\hline \multirow[t]{2}{*}{ Derecelendirme yapılması } & Evet & 189 & $\% 54,5$ \\
\hline & Hayır & 158 & $\% 45,5$ \\
\hline \multirow[t]{2}{*}{ Yorum ve öneri yapılması } & Evet & 157 & $\% 45,2$ \\
\hline & Hayır & 190 & $\% 54,8$ \\
\hline \multirow{2}{*}{$\begin{array}{l}\text { Yeni üründe diğer yorum ve derecelendirmeleri dikkate } \\
\text { alma }\end{array}$} & Evet & 308 & $\% 88,8$ \\
\hline & Hayır & 39 & $\% 11,2$ \\
\hline \multirow{5}{*}{ E-ticaret sitesi kullanımı } & $1-2$ yil & 101 & $\% 29,1$ \\
\hline & 3-4 yil & 97 & $\% 28,0$ \\
\hline & $5-6$ yil & 70 & $\% 20,2$ \\
\hline & $7-8$ yil & 35 & $\% 10,1$ \\
\hline & 9-10 yıl & 27 & $\% 7,8$ \\
\hline
\end{tabular}


E. Durukal - M. Doğaner - E. Armağan 11/1 (2019) 129-143

\begin{tabular}{|l|l|r|r|}
\hline & 11 yıl ve üzeri & 15 & $\% 4,3$ \\
\hline \multirow{3}{*}{$\begin{array}{l}\text { Seçilen sitenin en çok hangi sosyal medya platformunda } \\
\text { takip edildiği }\end{array}$} & Facebook & 139 & $\% 40,1$ \\
\cline { 2 - 4 } & İnstagram & 116 & $\% 33,4$ \\
\cline { 2 - 4 } & Linkedn & 26 & $\% 7,5$ \\
\cline { 2 - 4 } & Twitter & 11 & $\% 3,2$ \\
\cline { 2 - 4 } & Diğer & 55 & $\% 15,8$ \\
\hline \multirow{5}{*}{ En fazla kullandı̆̆ınız e-ticaret sitesi } & Trendyol.com & 93 & $\% 26,8$ \\
\cline { 2 - 4 } & Hepsiburada.com & 72 & $\% 20,7$ \\
\cline { 2 - 4 } & Gittigidiyor.com & 41 & $\% 11,8$ \\
\cline { 2 - 4 } & Sahibinden.com & 38 & $\% 11,0$ \\
\cline { 2 - 4 } & N11.com & 33 & $\% 9,5$ \\
\cline { 2 - 4 } & Yemetsepeti.com & 32 & $\% 9,2$ \\
\cline { 2 - 4 } & Diğer & 38 & $\% 11,8$ \\
\hline
\end{tabular}

Yeni ürün satın alırken diğer yorum ve derecelendirmeleri dikkate alma hususu incelendiğinde, katılımcıların \% 88,8'inin sosyal medyadaki diğer kullanıcıların yorum ve önerilerini ciddi ölçüde dikkate aldığ 1 buda e-ticarette sosyal medya pazarlamasının etkin bir şekilde kullanıldığ sonucunu ortaya çıkarmaktadır. Ayrıca araştırmaya katılanların seçtikleri e-ticaret sitelerini en çok \%40,1 ile facebook sosyal medya platformundan takip ettiği ve en fazla \% 26, 8 ile trendyol.com e-ticaret sitesini kullandıkları görülmektedir.

Bu sonuçlar doğrultusunda; günümüz müşterilerinin giderek dijitalleştiği, online alışverişe doğru yöneldiği bu ortamda, müşterilerin ürün satın alırken sosyal medyayı etkin olarak kullanarak ve diğer müşteriler ile sosyal medyada etkileşim içerisinde bulunarak onların görüş ve önerilerini dikkate alarak alışveriş yaptıklarını söyleyebiliriz.

\subsection{Güvenilirlik Analizi ve Yapısal Eşitlik Modeli}

Duygusal değerler, kişilik, bilgi, beceri ve tutum testlerinde uygulanan güvenilirlik analizi, kullanılan ölçeğin araştırma sorununu ne ölçüde yansıttığını ölçerken, ölçekte ifade edilen soruların birbirleri arasında tutarlılılı̆̆ını, anketlerin özelliklerini ve kullanılan testlerin güvenilirliklerini de ölçmek amacıyla geliştirilmiş bir metoddur (Kalaycı, 2010: 405; Tavakol ve Dennick, 2011: 53; Can, 2013: 343).

Tablo 3. Güvenilirlik Analizi

\begin{tabular}{|c|c|}
\hline Cronbach's Alpha & N of Items \\
\hline, 925 & 26 \\
\hline
\end{tabular}

Ölçeğin cronbach alpha güvenilirlik katsayısı $0.90 \leq \alpha<1.00$ yüksek derecede güvenilir (Can, 2013:343; Kalayc1, 2010: 405) olduğu kabul edildiğinde, Tablo 3'e göre araştırmanın cronbach's katsayısı yüksek derecede güvenilirdir.

Faktör analizine yönelik örneklem büyüklüğü açısından veri setinin uygunluğunu ölçmek için kullanılan Kaiser-Meyer-Olkin (KMO) istatistiği 0,50 ve üzerinde olması halinde örnek sayısı faktör analizi için yeterli olduğu söylenmektedir (Field, 2009, s. 647).

Tablo 4. KMO and Bartlett's Test

Kaiser-Meyer-Olkin Measure of Sampling Adequacy. Bartlett's Test of Sphericity

\begin{tabular}{|l|r|}
\hline Approx. Chi-Square &, 919 \\
\hline df & 4103,419 \\
\hline Sig. & 325 \\
\hline
\end{tabular}

Çalışmada KMO testi \% 91,9 (,919)'dur. 91,9 > 0,50 olduğu için faktör analizinin uygun olduğu görülmektedir. 
E. Durukal - M. Doğaner - E. Armağan 11/1 (2019) 129-143

Tablo 5 Açıklayıcı Faktör Analizinde Kullanılan Ölçekler ve İfade Kısaltmaları

\begin{tabular}{|l|c|l|}
\hline Ölçekler & İfade sayıs & İfade K1saltmaları \\
\hline Etkileşimlilik (A) & 6 & $\mathrm{~A} 1, \mathrm{~A} 2, \mathrm{~A} 3, \mathrm{~A} 4, \mathrm{~A} 5, \mathrm{~A} 6$ \\
\hline Bilişim (B) & 4 & $\mathrm{~B} 1, \mathrm{~B} 2, \mathrm{~B} 3, \mathrm{~B} 4$ \\
\hline Kişiselleştirme (C) & 4 & $\mathrm{C} 1, \mathrm{C} 2, \mathrm{C} 3, \mathrm{C} 4$ \\
\hline Trend (D) & 4 & $\mathrm{D} 1, \mathrm{D} 2, \mathrm{D} 3, \mathrm{D} 4$, \\
\hline E-WOM (E) & 4 & $\mathrm{E} 1, \mathrm{E} 2, \mathrm{E} 3, \mathrm{E} 4$ \\
\hline E-Sadakat (F) & 4 & $\mathrm{~F} 1, \mathrm{~F} 2, \mathrm{~F} 3, \mathrm{~F} 4$ \\
\hline
\end{tabular}

İlk kez açıklayıcı faktör analizi ile ilgili deneme yapıldığında, toplam varyans içerisinde \% 64,256'sını açıklayan 6 faktör ortaya çıkmıştır. Analiz sonuçlarına göre;

İki faktör yükü arasında olan mutlak fark 0,10 değerinin altında olduğu B3 ifadesinde görülmektedir.

Doğrulayıcı faktör analizini yapabilmek için ortaya çıkan açıklayıcı faktör analizi sonuçlarının uygun olmadığı sonucuna varılmıştır. Bu faktörler içerisinde uygun olmayan ifadeler ölçekten çıkarılmış ve tekrar analiz yapılmıştır. Faktör analizi ikinci kez yapıldı̆̆ında toplam varyansın \% 71,123'ünü açıklayan 6 faktör ortaya çıkmıştır. Toplam varyansın \%40 ile \%60 arasında olması sosyal bilimler alanında yeterli olduğu kabul edilmektedir (Osborne ve Costello, 2009: 138). Bu varsayımdan yola çıkarak \%71, 123 toplam varyans değeri araştırma için yeterli bir sonuç olarak kabul edilmiştir. Analiz sonucu ortaya çıkan faktörlerin dağılımı ve t-değerleri aşağıdaki Tablo 6’ da gösterilmektedir.

Tablo 6 Açıklayıcı Faktör Analizi Sonuçları ve t değerleri

\begin{tabular}{|c|c|c|c|c|c|c|c|}
\hline Faktörler & \begin{tabular}{|c|} 
Gözlenen \\
Değişkenler
\end{tabular} & $\begin{array}{l}\text { Faktör } \\
\text { Yükleri }\end{array}$ & $\begin{array}{c}t \\
\text { değerleri }\end{array}$ & Faktörler & $\begin{array}{c}\text { Gözlenen } \\
\text { Değişkenler }\end{array}$ & $\begin{array}{l}\text { Faktör } \\
\text { Yükleri }\end{array}$ & $\begin{array}{c}t \\
\text { değerleri }\end{array}$ \\
\hline \multirow{6}{*}{$\begin{array}{l}\text { Etkişimlilik } \\
\text { (A) }\end{array}$} & A1 & 697 & 10,52 & \multirow[t]{4}{*}{ Trend (D) } & D1 & ,598 & 10,54 \\
\hline & A2 & 670 & 10,57 & & D2 & ,551 & 8,22 \\
\hline & A3 & ,773 & 10,85 & & D3 & 695 & 12,38 \\
\hline & A4 & 603 & 11,62 & & D4 & 617 & 11,50 \\
\hline & A5 & 626 & 11,70 & \multirow[t]{4}{*}{ E-WOM (E) } & E1 & ,641 & 11,27 \\
\hline & A6 & ,541 & 11,80 & & E2 & 767 & 9,36 \\
\hline \multirow[t]{3}{*}{ Bilişim (B) } & B1 & ,566 & 9,59 & & E3 & ,672 & 11,80 \\
\hline & B2 & ,620 & 10,62 & & E4 & ,596 & 12,16 \\
\hline & B4 & 698 & 11,11 & \multirow[t]{5}{*}{ E-Sadakat (F) } & F1 & 406 & 12,11 \\
\hline \multirow{4}{*}{$\begin{array}{l}\text { Kişiselleştir } \\
\text { me (C) }\end{array}$} & $\mathrm{C} 1$ & 625 & 11,61 & & $\mathrm{~F} 2$ & ,656 & 11,64 \\
\hline & $\mathrm{C} 2$ & ,524 & 9,28 & & F3 & ,687 & 13,11 \\
\hline & C3 & ,686 & 10,75 & & F4 & ,602 & 11,79 \\
\hline & C4 & ,700 & 11,40 & & & & \\
\hline
\end{tabular}

Tablo 6'daki sonuçlar dikkate alındığında gözlenen değişkenler için hesaplanan $t$ değerlerinin en küçüğünün 8,22 değerine sahip olduğu görülmektedir. Bu doğrultuda e-ticarette algılanan sosyal medya pazarlaması boyutlarının e-sadakat üzerine etkisinin kabülünde yer alan gözlenen değişkenlerin ilgili gizil değişkenlerin göstergesi olduğu kabul edilebilir ( $p>0,05)$.

Daha önceki bilimsel çalışmalarda kullanılan ve bu araştırma modelinde yer alan gizil değişkenler, test edilmiş ölçekler yardımıyla ölçülmüştür. Toplam 25 sorunun temsil ettiği gözlenen değişkenler 6 gizil değişkeni açıklamaktadır. Tablo 7'de ölçekte yer alan ifade sayıları ve Cronbach's Alpha katsayısı ve açıkladığı varyans oranı bulunmaktadır.

Tablo 7 Cronbach's Alpha Değerleri

\begin{tabular}{|l|r|r|r|}
\hline Ölçekler & Ifade sayısı & Cronbach's alpha & \multicolumn{1}{c|}{ Özdeğer } \\
\hline Etkişimlilik (A) & 6 &, 805 & 13,543 \\
\hline Bilişim (B) & 3 &, 715 & 11,413 \\
\hline Kişiselleştirme (C) & 4 &, 742 & 12,320 \\
\hline Trend (D) & 4 &, 748 & 11,487 \\
\hline E-WOM & 4 &, 815 & 10,972 \\
\hline E-Sadakat & 4 &, 660 & 11,185 \\
\hline
\end{tabular}


Cronbach's alpha katsayısının 0.70 ve üzeri olması durumunda güvenilir olduğu ve testlere uygulanmasının açılanmasına rağmen (Cronbacha, 1951: 309), Nunnally'in sosyal bilimler alanında belirlediği alfa katsayısının 0.60 düzeyinde olmasının yeterli görülmesi (Er, 2011:180) tüm ölçeklerin yeterli düzeyde güvenilir olduğu sonucunu ortaya çıkarmıştır.

Modelin toplanan veriler ile sağlanıp sağlanamadığının incelenebilmesi için uyum iyiliği indekslerinin de incelenmesi gerekmektedir (Çapık, 2014: 200). En çok kullanılan uyum indekslerinin kabul edilebilir ve normal değerleri Tablo 8 ve Tablo 9'da görüldüğü gibidir.

Tablo 8 Faktörlerin Uyum İndeksleri ve Yapısal Modeli

\begin{tabular}{|c|r|r|r|r|r|r|}
\hline \multirow{2}{*}{ Uyum Ölçüsü } & \multicolumn{7}{|c|}{ Faktörler } \\
\cline { 2 - 7 } & \multicolumn{1}{|c|}{ A } & \multicolumn{1}{c|}{ B } & \multicolumn{1}{c|}{ C } & \multicolumn{1}{c|}{ D } & \multicolumn{1}{c|}{ E } & \multicolumn{1}{c|}{ F } \\
\hline $\begin{array}{c}\text { p value for test of close } \\
\text { fit (RMSEA }<0.05)\end{array}$ & 0.00 & 1.00 & 0.03 & 0.00 & 0.07 & 0.00 \\
\hline RMSEA & & & & & & \\
\hline GFI & 0.16 & 0.00 & 0.08 & 0.23 & 0.07 & 0.12 \\
\hline AGFI & 0.92 & & 0.99 & 0.95 & 0.99 & 0.98 \\
\hline NNFI & 0.82 & & 0.95 & 0.74 & 0.96 & 0.92 \\
\hline CFI & 0.87 & & 0.97 & 0.75 & 0.98 & 0.91 \\
\hline SRMR & 0.92 & & 0.99 & 0.92 & 0.99 & 0.97 \\
\hline
\end{tabular}

Tablo 9 Araştırma Modelinin Uyum İndeksleri ve Yapısal Modeli

\begin{tabular}{|c|c|c|}
\hline Uyum Ölçüsü & Karar kriterleri & Araştırma Sonucu \\
\hline$\chi 2$ & $\chi 2<0.05$ & $967.91 \mathrm{p}=0.0$ \\
\hline$\chi 2 /$ sd & $5 \leq \chi 2 /$ sd $\leq 2$ & 3.58 \\
\hline RMSEA & $0.08<$ RMSEA $<0.05$ & 0.076 \\
\hline GFI & GFI $>0.95$ & 0.82 \\
\hline AGFI & AGFI $>0.95$ & 0.78 \\
\hline NNFI & NNFI $>0.90$ & 0.94 \\
\hline CFI & CFI $>0.95$ & 0.95 \\
\hline SRMR & $0.10<$ SRMR $<0.05$ & 0.07 \\
\hline
\end{tabular}

Araştırmada modelin uyum indeksleri incelendiğinde ilk olarak gözlenen ve tahmin edilen kovaryans arasındaki tutarlılığı ölçmek için ki-kare değerinin incelenmesi gerekmektedir. Çalışmada ki-kare değeri 967,91 olarak hesaplanmıştır ve $(p<0,05)$ sonucuna göre istatistiksel olarak anlamlı olduğu görülmektedir. Bu sonuç ki-kare değerinin anlamlı çıkması örneklem sayısının 200' den fazla olduğu durumlarda beklenilen bir durum olarak görülmektedir (Hu ve Bentler, 1999: 2). Ki-kare değerinin literatürde genelde yerine kikare değerinin serbestlik derecesine bölünmesiyle elde edilen $\chi 2 /$ sd değerine bakılması önerilmektedir (Hair vd., 2010: 668). Araştırmada $\chi 2 /$ sd değeri 3,58 sonucunun ortaya çıkması $(5 \leq \chi 2 / \mathrm{sd} \leq 2)$ belirli bir kabul edilebilir limit değere sahip olduğu ve istatistiksel olarak anlamlı olduğu görülmektedir $(p<0,05)$. Araştırma modelinde diğer uyum indeksleri incelendiğinde, ana kütlede yaklaşık uyumun bir ölçüsü olan RMSEA değeri 0,076 değeri ise kabul edebilir bir düzeyde uyum iyiliği olarak görülmektedir.

Modelin kabul edilebilir düzeyde uyum gösterdiği GFI VE AGFI değerlerinin 0,95'in üzerinde olması sonucu, araştırmada da GFI değeri 0,82 ve AGFI değerinin ise 0,78 olarak hesaplanması, araştırmada hem GFI değeri hem de AGFI değerinin desteklenmediği görülmektedir. Ancak model uyum indekslerinden AGFI ve GFI indeks değerlerinin örneklem genişliğinden etkilenmesi durumu söz konusu oluğu için (Fan ve Sivo, 2005, s.365) literatürde model uyumunda bu iki indeksin kullanılmaması önerilmektedir (Sharma vd., 2005: 942). NNFI değerinin 0.90 'nın üzerinde olmasının kabul edilebilir bir uyuma sahip olması, araştırmada NNFI uyum iyiliği indeksi değerinin 0,94 olarak hesaplanması, modelde NNFI değeri kabul edilebilir uyuma sahip olduğunu göstermektedir. CFI değerinin 0,95 olarak hesaplanması kabul edilebilir değer olan 0,95'ın üzerinde bir değer alması modelin uyum iyiliğine sahip olduğunu göstermektedir (Hu ve Bentler, 1999: 27). SRMR değerinin 0,071 olarak hesaplanması da toplanan veriler ile kurulan model arasında kabul edilebilir bir uyumu söz konusudur (Hu ve Bentler, 1999:30). Bir bütün olarak uyum iyiliği indeksleri 
incelendiğinde GFI, AGFI, dışında diğer indekslerin önerilen sınırlar içerisinde kaldığı görülmektedir. Buna göre modelin genel olarak toplanan veriler ile doğrulandığg ifade edilebilir.

Rezaei, 2015'e göre; t-değerinin 2,58'in üzerinde olması değişkenler arasında pozitif ve anlamlı bir ilişki olduğunu ve t-değerlerinin kabul edilebilir sinırda olduğunu göstermektedir. Bu değerler dikkate alındığında modeldeki tüm değişkenler arasındaki ilişki anlamlı ve pozitif sonucu araştırma modelini destekleyen bir sonuç ortaya çıkarmaktadır.

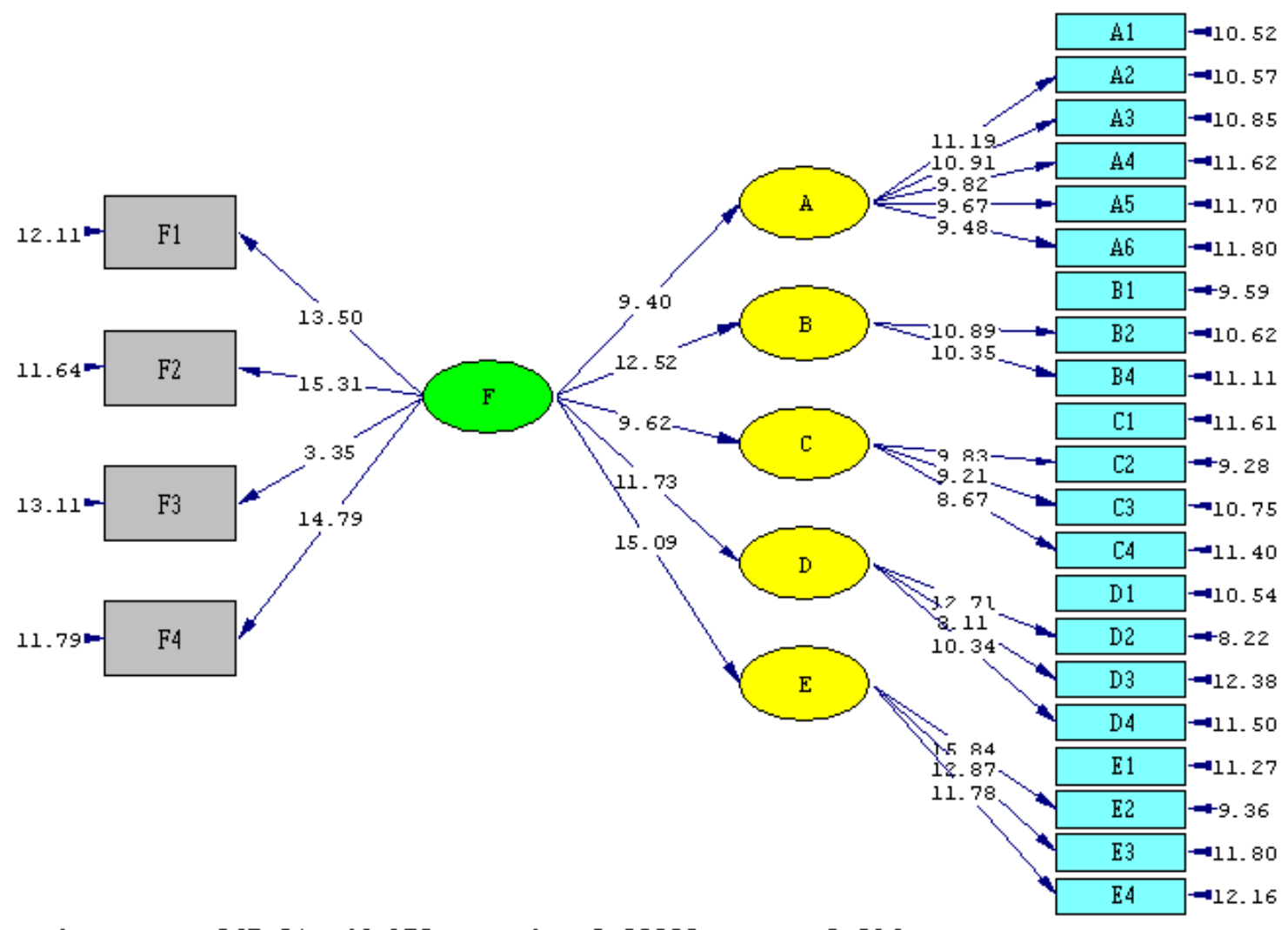

Chi-Square $=967.91, d f=270$, P-value $=0.00000$, RMSEA $=0.086$

Şekil 2 Araştırmanın Sonuç Modeli t-değerleri

Aşağıdaki Tablo 10'da; yapısal modeline ilişkin hesaplanan yol katsayısı değerleri ve onlara ait $\mathrm{t}$-değerleri ve araştırma hipotezlerinin sonuçları yer almaktadır.

Tablo 10 Yapısal Eşitlik Modelinde Yol katsayısı ve t-değerleri

\begin{tabular}{|l|r|r|c|}
\hline Hipotez & Yol katsayısı & $\mathbf{t}$-değerleri & Sonuç \\
\hline $\begin{array}{l}\text { H1:Algılanan sosyal medya pazarlaması etkileşimlilik } \\
\text { boyutunun e-sadakate olumlu etkisi vardır. }\end{array}$ & 0,56 & 9,40 & Kabul \\
\hline $\begin{array}{l}\text { H2: Algılanan sosyal medya pazarlaması bilişim boyutunun e- } \\
\text { sadakate olumlu etkisi vardır. }\end{array}$ & 0,85 & 12,52 & Kabul \\
\hline $\begin{array}{l}\text { H3: Alg1lanan sosyal medya pazarlaması kişiselleştirme } \\
\text { boyutunun e-sadakate olumlu etkisi vardır. }\end{array}$ & 0,62 & 9,62 & Kabul \\
\hline $\begin{array}{l}\text { H4: Algılanan sosyal medya pazarlaması trend boyutunun e- } \\
\text { sadakate olumlu etkisi vardır. }\end{array}$ & 0,80 & 11,73 & Kabul \\
\hline $\begin{array}{l}\text { H5: Algılanan sosyal medya pazarlaması e-wom boyutunun e- } \\
\text { sadakate olumlu etkisi vardır. }\end{array}$ & 0,92 & 15,09 & Kabul \\
\hline
\end{tabular}

Araştırma sonuçlarına göre tüm hipotezler desteklenmiştir. Ayrıca hipotezlerdeki yol katsayılarının 0,92 $(\mathrm{p}<0,05)$ olduğu görülmektedir. Bu sonucu göre kurulan modelin tüm hipotezleri açıkladığı ve en yüksek 
E. Durukal - M. Doğaner - E. Armağan 11/1 (2019) 129-143

açıklayan hipotezin H5 olduğu ve e-wom boyutunun e-sadakate etkisinin en yüksek açıklandığı görülmektedir.

\subsection{Değişkenler Arası Bulguların Analizi}

Araştırmada medeni durum ve cinsiyet değişkenlerinin faktörler açısından anlamlı bir fark olup olmadığını araştırmak amacıyla t-testi yapılmıştır. İki örneklem grubu arasında ortalamalar açısından fark olup olmadığını araştırmak için kullanılan t-testi parametrik bir test olarak adlandırılmaktadır (Can, 2013: 116; Kalayc1, 2014: 74).

Tablo 11. Cinsiyet Değişkenine Göre t-Testi Sonuçları

\begin{tabular}{|c|c|c|c|c|c|c|}
\hline Ölçek & Değişken & $\mathbf{N}$ & $\mu$ & Ss & Df & $\mathbf{P}$ \\
\hline \multirow[t]{2}{*}{ ETKİLEŞİMLİLİK } & Kadın & 212 & 3,5346 & ,57631 & \multirow[t]{2}{*}{347} & \multirow{2}{*}{,003 } \\
\hline & Erkek & 135 & 3,4951 & 77238 & & \\
\hline \multirow[t]{2}{*}{ BİLIŞ̧iM } & Kadın & 212 & 3,7469 & 65741 & \multirow[t]{2}{*}{347} & \multirow{2}{*}{,047 } \\
\hline & Erkek & 135 & 3,6691 & ,79644 & & \\
\hline \multirow[t]{2}{*}{ KİŞİSELLEŞTİRME } & Kadın & 212 & 3,6415 & ,61045 & \multirow[t]{2}{*}{347} & \multirow{2}{*}{,002 } \\
\hline & Erkek & 135 & 3,5222 & 80197 & & \\
\hline \multirow[t]{2}{*}{ TREND } & Kadın & 212 & 3,6226 & ,66856 & \multirow[t]{2}{*}{347} & \multirow{2}{*}{,019 } \\
\hline & Erkek & 135 & 3,4426 & 80283 & & \\
\hline \multirow[t]{2}{*}{ E-WOM } & Kadın & 212 & 3,6061 & 71166 & \multirow[t]{2}{*}{347} & \multirow{2}{*}{,010 } \\
\hline & Erkek & 135 & 3,5463 & 86451 & & \\
\hline \multirow[t]{2}{*}{ E-SADAKAT } & Kadın & 212 & 3,3573 & ,59668 & \multirow[t]{2}{*}{347} & \multirow{2}{*}{,008 } \\
\hline & Erkek & 135 & 3,2944 & ,76164 & & \\
\hline
\end{tabular}

Tablo 11 incelendiğinde cinsiyet değişkeni araştırmanın tüm boyutlarında $(\mathrm{p}<.05)$ anlamlı bir farklılık yaratmış ve etki cinsiyete göre farklılık göstermektedir. Bu sonuçlara göre de cinsiyet değişkenin e-ticarette algılanan sosyal medya pazarlaması ve e-sadakat üzerinde belirleyici bir unsur olduğu söylenebilir. Ortalamalar açısından incelendiğinde ise kadınların erkeklere göre e-sadakatleri ve e-ticarette sosyal medya pazarlaması algıları daha yüksektir.

Tablo 12. Medeni Durum Değişkenlerine Göre t-Testi Sonuçlar

\begin{tabular}{|c|c|c|c|c|c|c|}
\hline & & $\mathbf{N}$ & $\mu$ & Ss & Df & $\mathbf{P}$ \\
\hline \multirow[t]{2}{*}{ ETKİLEŞİMLİLIKK } & Bekar & 151 & 3,5519 & 69580 & \multirow[t]{2}{*}{347} & \multirow{2}{*}{ 208 } \\
\hline & Evli & 196 & 3,4940 & 62938 & & \\
\hline \multirow[t]{2}{*}{ BİLIŞìM } & Bekar & 151 & 3,6909 & 80471 & \multirow[t]{2}{*}{347} & \multirow{2}{*}{, 020} \\
\hline & Evli & 196 & 3,7364 & 63803 & & \\
\hline \multirow[t]{2}{*}{ KISŞİSELLESTİRME } & Bekar & 151 & 3,5712 & ,74183 & \multirow[t]{2}{*}{347} & \multirow{2}{*}{,301 } \\
\hline & Evli & 196 & 3,6135 & 65354 & & \\
\hline \multirow[t]{2}{*}{ TREND } & Bekar & 151 & 3,5480 & 77659 & \multirow[t]{2}{*}{347} & \multirow{2}{*}{ 131 } \\
\hline & Evli & 196 & 3,5561 & 69016 & & \\
\hline \multirow[t]{2}{*}{ E-WOM } & Bekar & 151 & 3,6060 & ,83289 & \multirow[t]{2}{*}{347} & \multirow{2}{*}{ 152 } \\
\hline & Evli & 196 & 3,5651 & ,72716 & & \\
\hline \multirow[t]{2}{*}{ E-SADAKAT } & Bekar & 151 & 3,3593 & 71156 & \multirow[t]{2}{*}{347} & \multirow{2}{*}{ 180 } \\
\hline & Evli & 196 & 3,3125 & 62858 & & \\
\hline
\end{tabular}

Tablo 12 incelendiğinde medeni durum değişkeni araştırmanın bilişim boyutu dişındaki diğer tüm boyutlarında ( $\mathrm{p}>.05$ ) anlamlı bir farklılık yaratmamış ve etki medeni duruma göre farklılık göstermemektedir. Bu sonuçlara göre de medeni durum değişkenin e-ticarette algılanan sosyal medya pazarlaması ve e-sadakat üzerinde bilişim boyutu dışında belirleyici bir unsur olmadığı söylenebilir. Ortalamalar açısından incelendiğinde ise evli bireylerin bekar bireylere göre bilişim boyutunda daha yüksek bir algıya sahip olduğu söylenebilir. 
E. Durukal - M. Doğaner - E. Armağan 11/1 (2019) 129-143

Araştırmada yaş, eğitim, gelir durumu, çalışma durumu gibi iki ya da daha fazla ortalama arasında fark olup olmadığını test etmek amacıyla varyans analizi (ANOVA) testi yapılmıştır. ANOVA testinde hipotezi test etmek için $\mathrm{F}$ değeri kullanılmaktadır.

Tablo 13. Tüketicilerin Değişkenlerine Göre ANOVA Testi Sonuçlar

\begin{tabular}{|c|c|c|c|c|c|c|c|c|}
\hline & \multicolumn{2}{|c|}{ YAŞ } & \multicolumn{2}{|l|}{ EĞİTİM } & \multicolumn{2}{|c|}{$\begin{array}{l}\text { ÇALIŞMA } \\
\text { DURUMU }\end{array}$} & \multicolumn{2}{|l|}{ GELİR } \\
\hline & $\begin{array}{l}\mathbf{F} \\
\text { Değeri }\end{array}$ & $\begin{array}{l}P \\
\text { değeri }\end{array}$ & $\begin{array}{l}F \\
\text { Değeri }\end{array}$ & $\begin{array}{l}\mathbf{P} \\
\text { değeri }\end{array}$ & $\begin{array}{l}\mathbf{F} \\
\text { Değeri }\end{array}$ & $\begin{array}{l}\mathbf{P} \\
\text { değeri }\end{array}$ & $\begin{array}{l}\mathbf{F} \\
\text { Değeri }\end{array}$ & $\begin{array}{l}P \\
\text { değeri }\end{array}$ \\
\hline ETKİLEŞIMMLİLIK & 1,937 & 088 & 1,289 & 274 & 1,246 & 288 & 1,234 & 279 \\
\hline BİLİşìM & 1,242 & ,289 & 80471 & 317 & ,935 & ,459 & 2,124 & ,034 \\
\hline KİSíSELLESTİRME & 1,664 & , 143 & 74183 & ,289 & ,387 & 858 & 1,264 & ,262 \\
\hline TREND & 1,122 & ,348 & 77659 & ,996 & 1,335 & ,250 & 2,662 & ,008 \\
\hline E-WOM & ,448 & ,815 & ,83289 & 347 & 1,249 & 286 & 2,298 & 021 \\
\hline E-SADAKAT & ,166 & ,975 & 71156 & ,542 & 2,659 & ,023 & 1,639 & 114 \\
\hline
\end{tabular}

Tablo 13 incelendiğinde yaş, eğitim durumu ve çalışma durumu değişkeni araştırmanın tüm boyutlarında ( $\mathrm{p}$ >.05) anlamlı bir farklılık yaratmamış ve etki yaşa, eğitim durumu ve çalışma durumuna göre farklılık göstermemektedir. Bu sonuçlara göre de yaş, eğitim durumu ve çalışma durumu değişkenin e-ticarette algılanan sosyal medya pazarlaması ve e-sadakat üzerinde belirleyici bir unsur olmadığı söylenebilir. Tablo 13 incelendiğinde gelir değişkeni $(\mathrm{p}<.05$ ) anlamlı bir farklılık yaratmış ve etki gelir durumuna göre farklılık göstermektedir. Bu sonuçlara göre de gelir değişkenin e-ticarette algılanan sosyal medya pazarlaması ve esadakat üzerinde belirleyici bir unsur olduğu söylenebilir.

\section{Sonuç ve tartışma}

Dünya ekonomisi günümüzde tarım ekonomisinden hizmet ekonomisine dönüşmüş ve hizmet sektörüne verilen önem giderek artmıştır. Gelişmiş ülkelerin GSMH içerisindeki hizmet sektörünün payı her geçen gün artmış ve ülkemizde bu artışla birlikte bu dönüşüme uyum göstermiştir. Hizmet sektörü işletmelerinin en fazla ağırlık verdiği alanların başında dijital dönüşümün başı çektiği uygulama e-ticaret faaliyetleri ve bir diğeri tüketicilerin oldukça önem verdikleri sosyal medya pazarlaması faaliyetleri olmaktadır. Günümüzün bilinçli tüketicileri alışveriş alışkanlarını değiştirmiş, zaman tasarrufu, dakiklik, karşılaştırma yapma gibi imkanların sağlandığı e-ticaret sitelerinden alışveriş yapmaya yönelmişlerdir. Bununla birlikte bu sitelerden alışveriş yapan tüketiciler diğer tüketiciler ile sosyal medya faaliyetlerinden yararlanarak görüşlerini, önerilerini, şikayetlerini dikkate alarak etkileşim kurmaktadırlar. Çalışmamızda e-ticaret sitesi kullanıcılarının algıladıkları sosyal medya pazarlaması faaliyetlerinin e-sadakate etkisi araştırılmıştır. Literatürde, e-ticaret sitesi kullanıcılarının algıladıkları sosyal medya pazarlaması faaliyetleri ile ilgili çalışmalar oldukça azdır. Bu çalışmanın temelini Yadav ve Rahman, (2017) çalışması ve ilave olarak esadakate etkisini incelediğimiz Al-Hawari, (2014) çalışması oluşturmaktadır.

Çalışmada tüketicilerin tamamına yakının sosyal medyayı hergün kullandığı sonucu, “Dijital in 2017 Global Overview" raporunda ülkemiz tüketicilerinin internette her gün geçirdikleri ortalama 7 saatin yaklaşı 3 saati sosyal medya kanallarında geçirmesi sonucunu destekler niteliktedir. Araştırmaya katılan tüketicilerin \% 77'sinin e-ticaret sitesi kullandığı ve \% 72'sinin ise sosyal medyada e-ticaret marka sayfalarını takip ettiği sonucu, e-ticaret sitesi kullanıcılarının büyük çoğunluğunun sosyal medyada e-ticaret sayfalarını kullandığını ortaya çıkarmaktadır. Araştırmaya katılan tüketicilerin yarısının e-ticaret sitelerine değerlendirme, yorum ve öneride bulundukları, yarısına yakınının e-ticaret sitelerinin sosyal medya ürün bağlantısından mal satın aldığı sonucu, "Dijital in 2017 Global Overview" raporunda Türkiye'de e-ticaret kullanıcılarının yüzde 43'ünün de satın almayı gerçekleştirdiği gerçeği göz önünde alındığında çalışmayı destekler nitelik taşımaktadır. Göze çarpan bir diğer çarpıcı sonuç, e-ticaret kullanıcılarının \% 89'unun yeni ürün satın alırken diğer kullanıcıların yorum ve önerini dikkate aldığıdır. Bu sonuca bağlı olarak tüketicilerin e-ticaret sitelerinden daha çok sosyal medyadan aldıkları kullanıcı deneyimleri ve yorumlarından etkilendikleri, online topluluklar yoluyla diğer e-ticaret siteleri kullanıcıları ile kurdukları etkileşim ile daha iyi algıladıkları söylenebilir. 
Çalışmada, cinsiyet değişkeni tüm boyutlar üzerinde farklılık yaratmış, kadın e-ticaret kullanıcıları erkek kullanıcılara göre e-sadakatleri daha yüksek olduğu görülmüştür. Bunun için de kadınların e-ticaret alışveriş sitelerinde daha fazla vakit geçirdikleri, alışverişe daha meğilli oldukları, modayı, yeniliği daha fazla takip ettikleri şeklinde yorumlanabilir. Çalışmada sosyal medya pazarlamasının boyutlarından biri olan ewom'un e-sadakate etkisi, araştırma modelinin en fazla açıklayan sonucu çıkması, e-ticaret kullanıcılarının günümüzde e-ticaret hakkındaki deneyimlerini sosyal medyada büyük ölçüde paylaştıkları sonucunu desteklemektedir. Günümüz tüketicilerinin e-ticaret sitelerinin kendi tanıtımlarından daha ziyade, birbiriyle kurdukları iletişim ve paylaşım daha etkili olmaktadır. Sosyal medya pazarlaması faaliyetleri içerisinde ewom, müşterilerin e-ticaret sitelerini tekrar tercih etmeleri ve e-sadakat duymaları açısından oldukça önem taşımaktadır. Sosyal medya pazarlaması boyutlarından biri olan bilişimin e-wom'dan sonra e-sadakate etkisi en fazla açıklanmaktadır. Bu da e-ticaret sitelerinin tüketicilere yararlı, doğru, kapsamlı ve açıklayıcı bilgi sunmaları e-ticaret kullanıcılarının bu sitelere e-sadakat duyması açısından etkili olmaktadır. Sosyal medya pazarlaması boyutlarından bir diğeri olan trendin tüketicilerin e-ticaret sitelerine e-sadakat duymalarına etkili olmasında; bu sitelerin modaya uygun, kendilerini sürekli yenileyen bir içerik oluşturmalarından kaynaklandığını söyleyebiliriz. Sosyal medya pazarlaması boyutu kişiselleştirmenin e-ticaret kullanıcılarının bu sitelere e-sadakat duymalarının etkili olmasında, kullanıcılarına sunulan özel hizmetlerin oldukça fazla olması ve kullanıcılarında genel hizmetler yerine kendilerini özel hissettiren hizmetler verilmesinin bu sitelerine bağlılık duymaları açısından önem taşımaktadır. Ayrıca bir diğer boyut olan etkileşim, tüketicilerin aktif olarak diğer kullanıcılar ile görüşlerini paylaşma olanaklarının olması e-ticaret sitelerini tekrar tercih etmeleri ve bağlılık duymaları açısından önem taşımaktadır. Genel olarak günümüz tüketicilerinin işletmeleri tekrar tercih etmeleri ve sadakat duymaları açısından oldukça önemi artan sosyal medya pazarlaması faaliyetlerinin tüm boyutları e-ticaret sitesi kullanıcılarının algılamaları açısından etkili olduğu şeklinde özetlenebilir.

\section{Kaynakça}

Alan, A.K., Kabadayı, E., T. ve Uzunburun, T. (2018). "Sosyal medya pazarlama faaliyetlerinin müşteri varlığı ve müşteri bağlılığına etkisi", Uluslararası Yönetim İktisat ve İşletme Dergisi, 14 (2), 535-555.

Arslan, İ. Kahraman, P., B.(2018). “Tüketici satın alma davranışları üzerinde sosyal medyanın etkisi: Y kuşağı üzerine bir araştırma", İstanbul Ticaret Üniversitesi Sosyal Bilimler Dergisi, 17 (33), 269-286.

Akar, E., (2015). E-ticaret, Sosyal Ticaret, Mobil Ticaret Pazarlama Temelli Yaklaşım, Ankara, Seçkin Yayıncilik.

Al-Hawari, (2014). "Does customer sociability matter? Differences in e-quality, e-satisfaction and e-loyalty between introvert and extravert online banking users", Journal of Services Marketing, 28 (7), 538-546.

Barutçu, S. ve Tomaş, M. (2013). “Sürdürülebilir sosyal medya pazarlaması ve sosyal medya pazarlaması etkinliğinin ölçümü", İnternet Uygulamaları ve Yönetimi Dergisi, (1), 5-24.

Can, A.,(2013). SPSS ile Bilimsel Araştırma Sürecinde Nicel Veri Analizi, Ankara, Pegem Akademi.

Cui, Y., Niu, J. and Tang, L., (2017). "Effect of the online shopping value on e-satisfaction and e-loyalty", Economic Management Journal, 6 (1), 9-20.

Çapık, C. (2014). "Geçerlik ve güvenilirlik çalışmalarında doğrulayıcı faktör analizinin kullanımı”. Anadolu Hemşirelik ve Sağllk Bilimleri Dergisi, 17 (3), 196-204.

Fan, X. and Sivo, S. A. (2005). "Sensitivity of fit indexes to misspecified structural or measurement model components: rationale of two-index strategy revisited", Structural Equation Modeling, 12 (3), 343-367.

Field, A.P. (2009). Discovering statistics using SPSS, London: Sage.

Hair, J.F., Black, W.C., Babın, B.J. and Anderson, R.E. (2010). Multivariate Data Analysis a Global Perspective, Pearson Prentice Hall, Upper Saddle River. 
E. Durukal - M. Doğaner - E. Armağan 11/1 (2019) 129-143

Hannak, A., Soeller, G., Lazer, D., Mislove, A. and Wilson, C., (2014). “Measuring price discrimination and steering on e-commerce web sites", IMC'14, Proceeding of the 2014 Conference on Internet Measurement Conference, November 5-7, 2014:305:318, Vancouver, BC, Canada.

Hu, L. and Bentler, P. (1999). "Cut off criteria for fit indexes in covariance structure analysis: conventional criteria versus new alternatives", Structural Equation Modeling: A Multidisciplinary Journal, 6 (1), 1-55.

Kalaycı, Ş.,(2010).SPSS uygulamalı çok değişkenli istatistik teknikleri, Ankara, Asil.

Köker, N., E. ve Özgür, M. Y. (2018). “E-satın alma niyeti internet ve sosyal medya kullanımı tarafından pekiştiriliyor mu? Üniversite öğrencileri üzerine nicel bir araştırma”, Erciyes İletişim Dergisi, 5(4), 143162.

Lopez-Miguens, M. and Gonzalez Vazquez, E., (2017). “An integral model of e-loyalty from the consumer's perspective", Computers in Human Behavior, 72: 397-411.

Ludin, I. H. and Cheng, B. L., (2014). “Factors influencing customer satisfaction and e-loyalty: online shopping environment among the young adults", Management Dynamics in the Knowledge Economy, 2 (3), 462-471.

Tavakol, M. and Dennick, R. (2011). "Making sense of Cronbach's alfa". International Journal of Medical Education, 2, 53-55.

Osborne, J.W. and Costello, A.B. (2009). "Best practices in exploratory factor analysis: Four recommendations for getting the most from your analysis". Pan-Pacific Management Review, 12 (2), 131-146.

Rezaei, S. (2015). “Segmenting consumer decision-making styles (CDMS) toward marketing practice: A partial least squares (PLS) path modeling approach", Journal of Retailing and Consumer Services, 22, 115.

Sharma, S., Mukherjee, S., Kumar, A. and Dillon, W. R. (2005). “A simulation study to investigate the use of cut off values for assessing model fit in covariance structure models", Journal of Business Research, 58 (7), 945-943.

Sin, S.S., Nor, K.M. and Al-Agaga, A. M. (2012). Factors affecting malaysian young consumers' online purchase intention in social media websites. Procedia - Social and Behavioral Sciences 40 ( 2012 ) 326 333.

Seo, E. and Park, J. (2018). "A study on the effects of social media marketing activities on brand equity and customer response in the airline industry" Journal of Air Transport Management 66, 36-41.

Telli-Yamamoto, G. and Karamanlı-Şekeroğlu, Ö. (2014). Sosyal medya ve blog. İstanbul: Kriter Yayınevi.

TÜBİSAD Bilişim Sanayiciler Derneği, 2017, http://www.tubisad.org.tr/tr/images/pdf/tubisad 2018 e-ticaret, erişim 07 Eylül 2018.

Yadav, M. and Rahman Z., (2017). "Measuring consumer perception of social media marketing activities in e-commerce industry: scale development \& validation" Telematics and Informatics, Vol. 37, No. 7, 12971307.

Yang, Q., Wu, S., Wang, L., Wu, P., Chen, H. and Wei, G., (2016). “E-wom from e-commerce websites and social media: which will consumers Adopt?", Electronic Commerce Research and Applications, 17, 62-73.

Yaralı, E. S. ve Kırık, A.. M., (2017). “Türkiye'de facebook üzerinden e-ticaret uygulamaları: Tesbihane ve Çaykur Örneği”, International Journal of Social Science, Sayı 55, Bahar II: 525-542.

Zhao, W. X., Li, S., He, Y., Chang, E. Y. and Wen, J., (2016). “Connecting social media to e-commerce: coldstart product recommendation using microblogging information" Ieee Transactıons On Knowledge And Data Engineering, 10 (10), 1-14.

We are Social, Digital in 2018 Global Overview" (2018). https:/www.slideshare.net/wearesocial/digital-in2018-in-western-asia-part-1-northwest-86865983 